Pacific Journal of Mathematics

ZOLOTAREV'S THEOREM ON THE LEGENDRE SYMBOL 


\title{
ZOLOTAREV'S THEOREM ON THE LEGENDRE SYMBOL
}

J. L. BRENNER

Dedicated to Professor D. H. Lehmer

\begin{abstract}
Matrix-theoretic proof that $(a / p)=$ sign of the permutation $i(\bmod p) \rightarrow i a(\bmod p)$ of the residue classes $\bmod p$.
\end{abstract}

In [5], Zolotarev proved the quadratic reciprocity law on the basis of the above-stated result. Here is a short proof of that result; it uses matrix theory, together with a well-known result in number theory.

DeFinition 1. An $a$-circulant is an $n \times n$ matrix such that each row (except the first) is obtained from the preceding by shifting each element $a$ positions to the right.

Definition 2. $P=\left(p_{i j}\right)$ denotes the $n \times n$ permutation matrix that corresponds to the permutation $i \rightarrow i+1(\bmod n)$, i.e., $p_{12}=$ $p_{23}=\cdots=p_{n-1, n}=p_{n 1}=1 ; p_{i j}=0$ otherwise.

Note that $P^{a}$, the ath power of $P$, is an $a$-circulant.

Definition 3. $A(a)$ denotes the $a$-circulant, the first row of which has 1 in the ath column and zeros elsewhere.

Note that $P A(a)=A(a) P^{a}$.

THEOREM 4. Det $A(a)=$ sign of the permutation $i(\bmod n) \rightarrow$ $i a(\bmod n)$.

This follows from one of the usual definitions of the determinant function.

Lemma 5. If the first row of $A\left(a_{1}\right)$ is multiplied by the matrix $A\left(a_{2}\right)$, the product is: the row that has all zeros except for 1 in the position $a_{1} a_{2}(\bmod n)$. [Obvious.]

THEOREM 6. The product of an $a_{1}$-circulant by an $a_{2}$-circulant is an $a_{1} a_{2}$-circulant.

Proof. $P A\left(a_{1}\right) A\left(a_{2}\right)=A\left(a_{1}\right) A\left(a_{2}\right) P^{e}, e=a_{1} a_{2}$.

Corollary 7. $A\left(a_{1}\right) A\left(a_{2}\right)=A\left(a_{1} a_{2}\right)$;

$\operatorname{det} A\left(a_{1}\right) \operatorname{det} A\left(a_{2}\right)=\operatorname{det} A\left(a_{1} a_{2}\right)$.

CoRollary 8. For $(a, n)=1$, the determinant of the set $\{A(a)\}$ is a character $\bmod n$. 
LEMMA 9. If $a=g$ is a primitive root of the odd prime number $p=n$, then $\operatorname{det} A(g)=-1$.

Proof. The corresponding permutation is an $(n-1)$-cycle; its sign is -1 .

Theorem 10. If $n$ is an odd prime $p$, then $\operatorname{det} A(a)=(a / p)$, the Legendre symbol.

Proof. The Legendre symbol is the only real character modulo a prime that actually assumes the value -1 .

CoROLlary 11. [Zolotarev]. $(a / p)=$ sign of the permutation $i(\bmod p) \longrightarrow i a(\bmod p)$, where $p$ is a prime.

REMark. The result $\operatorname{det} A(\alpha)=(a / n)$ does hold in general [4]. When $n$ is an odd prime power, this is obvious since $n$ has a primitive root. For other odd $n$, it seems less obvious. See [2,3] for proof.

Concluding remark. As Zolotarev showed, the argument of this article furnishes yet another proof, and the first matrix-theoretic one, of the quadratic reciprocity law.

Acknowledgment. I thank Professor D. H. Lehmer for asking whether the methods developed in [1] could be used to prove that $\operatorname{det} A(a)=(a / p)$.

\section{REFERENCES}

1. C. M. Ablow and J. L. Brenner, Roots and canonical forms of circulant matrices, Trans. Amer. Math. Soc., 107 (1963), 360-376.

2. J. L. Brenner, A new property of the Jacobi symbol, Duke Math. J., 29 (1962), 29-32.

3. D. H. Lehmer, Mahler's matrices, Notices of the Amer. Math. Soc., 1, 365. abstract 569-50; Australian J. Math., I (1959/60), 385-395.

4. M. Riesz, Sur le lemme de Zolotareff et sur la loi de réciprocité des restes quadratiques, Math. Scand., 1 (1953), 159-169.

5. G. Zolotareff, Nouvelle démonstration de la loi de réciprocité de Legendre, Nouvelles Annales de Math. (ser. 2) 11 (1872), 354-362.

Received February 2, 1972. Supported by NSF Grant GP-32527.

UNIVERSity OF Victoria, CANADA

AND

College of Notre Dame, Belmont, California 


\section{PACIFIC JOURNAL OF MATHEMATICS}

\section{EDITORS}

\author{
H. SAMELson \\ Stanford University \\ Stanford, California 94305 \\ C. R. HоввY \\ University of Washington \\ Seattle, Washington 98105
}

J. DugundJI

Department of Mathematics

University of Southern California

Los Angeles, California 90007

RICHARD ARENS

University of California

Los Angeles, California 90024

\section{ASSOCIATE EDITORS}
E. F. BeCKENBACH
B. H. NEUMANN
F. WOLF
K. YoshidA

\section{SUPPORTING INSTITUTIONS}

UNIVERSITY OF BRITISH COLUMBIA

CALIFORNIA INSTITUTE OF TECHNOLOGY

UNIVERSITY OF CALIFORNIA

MONTANA STATE UNIVERSITY

UNIVERSITY OF NEVADA

NEW MEXICO STATE UNIVERSITY

OREGON STATE UNIVERSITY

UNIVERSITY OF OREGON

OSAKA UNIVERSITY

\author{
UNIVERSITY OF SOUTHERN CALIFORNIA \\ STANFORD UNIVERSITY \\ UNIVERSITY OF TOKYO \\ UNIVERSITY OF UTAH \\ WASHINGTON STATE UNIVERSITY \\ UNIVERSITY OF WASHINGTON

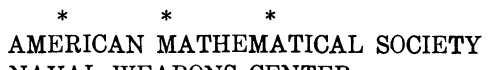 \\ NAVAL WEAPONS CENTER
}

The Supporting Institutions listed above contribute to the cost of publication of this Journal, but they are not owners or publishers and have no responsibility for its content or policies.

Mathematical papers intended for publication in the Pacific Journal of Mathematics should be in typed form or offset-reproduced, (not dittoed), double spaced with large margins. Underline Greek letters in red, German in green, and script in blue. The first paragraph or two must be capable of being used separately as a synopsis of the entire paper. The editorial "we" must not be used in the synopsis, and items of the bibliography should not be cited there unless absolutely necessary, in which case they must be identified by author and Journal, rather than by item number. Manuscripts, in duplicate if possible, may be sent to any one of the four editors. Please classify according to the scheme of Math. Rev. Index to Vol. 39. All other communications to the editors should be addressed to the managing editor, Richard Arens, University of California, Los Angeles, California, 90024.

50 reprints are provided free for each article; additional copies may be obtained at cost in multiples of 50 .

The Pacific Journal of Mathematics is issued monthly as of January 1966. Regular subscription rate: $\$ 48.00$ a year (6 Vols., 12 issues). Special rate: $\$ 24.00$ a year to individual members of supporting institutions.

Subscriptions, orders for back numbers, and changes of address should be sent to Pacific Journal of Mathematics, 103 Highland Boulevard, Berkeley, California, 94708.

PUBLISHED BY PACIFIC JOURNAL OF MATHEMATICS, A NON-PROFIT CORPORATION

Printed at Kokusai Bunken Insatsusha (International Academic Printing Co., Ltd.), 270, 3-chome Totsuka-cho, Shinjuku-ku, Tokyo 160, Japan. 


\section{Pacific Journal of Mathematics}

\section{Vol. 45, No. $2 \quad$ October, 1973}

Kenneth Paul Baclawski and Kenneth Kapp, Induced topologies for quasigroups and loops ............................................. 393

D. G. Bourgin, Fixed point and $\min -\max$ theorems $\ldots \ldots \ldots \ldots \ldots \ldots \ldots$

J. L. Brenner, Zolotarev's theorem on the Legendre symbol ............... 413

Jospeh Atkins Childress, Jr., Restricting isotopies of spheres .............. 415

John Edward Coury, Some results on lacunary Walsh series ................ 419

James B. Derr and N. P. Mukherjee, Generalized Sylow tower groups. II . . . . . . 427

Paul Frazier Duvall, Jr., Peter Fletcher and Robert Allen McCoy, Isotopy Galois

spaces .......................................... 435

Mary Rodriguez Embry, Strictly cyclic operator algebras on a Banach space ... 443

Abi (Abiadbollah) Fattahi, On generalizations of Sylow tower groups ......... 453

Burton I. Fein and Murray M. Schacher, Maximal subfields of tensor products . . 479

Ervin Fried and J. Sichler, Homomorphisms of commutative rings with unit

element .......................................... 485

Kenneth R. Goodearl, Essential products of nonsingular rings ............. 493

George Grätzer, Bjarni Jónsson and H. Lakser, The amalgamation property in

equational classes of modular lattices ...........................

507

$\mathrm{H}$. Groemer, On some mean values associated with a randomly selected simplex

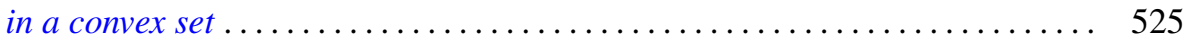

Marcel Herzog, Central 2-Sylow intersections .................... 535

Joel Saul Hillel, On the number of type-k translation-invariant groups ........ 539

Ronald Brian Kirk, A note on the Mackey topology for $\left(C^{b}(X)^{*}, C^{b}(X)\right) \ldots \ldots .543$

J. W. Lea, The peripherality of irreducible elements of lattice.............. 555

John Stewart Locker, Self-adjointness for multi-point differential operators ..... 561

Robert Patrick Martineau, Splitting of group representations ............... 571

Robert Massagli, On a new radical in a topological ring ................. 577

James Murdoch McPherson, Wild arcs in three-space. I. Families of Fox-Artin

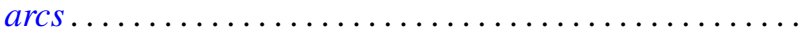

585

James Murdoch McPherson, Wild arcs in three-space. III. An invariant of

oriented local type for exceptional arcs . . . . . . . . . . . . ............ 599

Fred Richman, The constructive theory of countable abelian p-groups ........ 621

Edward Barry Saff and J. L. Walsh, On the convergence of rational functions

which interpolate in the roots of unity ..................

Harold Eugene Schlais, Non-aposyndesis and non-hereditary

decomposability..................................... 643

Mark Lawrence Teply, A class of divisible modules................... 653

Edward Joseph Tully, Jr., H-commutative semigroups in which each

homomorphism is uniquely determined by its kernel ................. 669

Garth William Warner, Jr., Zeta functions on the real general linear group ...... 681

Keith Yale, Cocyles with range $\{ \pm 1\} \ldots \ldots \ldots \ldots \ldots \ldots \ldots \ldots \ldots \ldots \ldots \ldots \ldots . \ldots \ldots$

Chi-Lin Yen, On the rest points of a nonlinear nonexpansive semigroup ........ 699 